\title{
SOIL SAMPLING INTENSITY AND SPATIAL DISTRIBUTION PATTERN OF SOILS ATTRIBUTES AND CORN YIELD IN NO-TILLAGE SYSTEM
}

\section{MARCOS S. RODRIGUES ${ }^{1}$, JOSÉ E. CORÁ ${ }^{2}$, CAROLINA FERNANDES ${ }^{3}$}

\begin{abstract}
Taking into account that the sampling intensity of soil attributes is a determining factor for applying of concepts of precision agriculture, this study aims to determine the spatial distribution pattern of soil attributes and corn yield at four soil sampling intensities and verify how sampling intensity affects cause-effect relationship between soil attributes and corn yield. A 100referenced point sample grid was imposed on the experimental site. Thus, each sampling cell encompassed an area of $45 \mathrm{~m}^{2}$ and was composed of five 10-m long crop rows, where referenced points were considered the center of the cell. Samples were taken from at 0 to $0.1 \mathrm{~m}$ and 0.1 to $0.2 \mathrm{~m}$ depths. Soil chemical attributes and clay content were evaluated. Sampling intensities were established by initial 100-point sampling, resulting data sets of 100; 75; 50 and 25 points. The data were submitted to descriptive statistical and geostatistics analyses. The best sampling intensity to know the spatial distribution pattern was dependent on the soil attribute being studied. The attributes $\mathrm{P}$ and $\mathrm{K}^{+}$content showed higher spatial variability; while the clay content, $\mathrm{Ca}^{2+}, \mathrm{Mg}^{2+}$ and base saturation values $(\mathrm{V})$ showed lesser spatial variability. The spatial distribution pattern of clay content and $\mathrm{V}$ at the 100-point sampling were the ones which best explained the spatial distribution pattern of corn yield.
\end{abstract}

KEYWORDS: geostatistics, precision agriculture, Zea mays.

\section{INTENSIDADE AMOSTRAL E DEFINIÇÃO DA DISTRIBUIÇÃO ESPACIAL DE ATRIBUTOS DO SOLO E DA PRODUTIVIDADE DE MILHO SOB SEMEADURA DIRETA}

RESUMO: Tendo em vista ser a intensidade amostral de atributos do solo um fator determinante para a aplicação dos conceitos de agricultura de precisão, este trabalho foi conduzido para determinar o padrão de distribuição espacial de atributos do solo e da produtividade de milho em quatro intensidades de amostragem de solo e verificar a influência da intensidade amostral na compreensão da relação de causa e efeito entre atributos do solo e produtividade. Para isto, utilizou-se uma malha amostral de 100 pontos referenciados, na qual cada célula amostral de $45 \mathrm{~m}^{2}$ era composta por cinco linhas de $10 \mathrm{~m}$ da cultura, onde o ponto referenciado foi considerado o centro da célula. As amostras foram realizadas nas profundidades de 0-0,1 e 0,1-0,2 m para avaliar atributos químicos e a textura do solo. A partir dos 100 pontos, obtiveram-se conjuntos de dados com 100; 75; 50 e 25 pontos amostrais. Os dados foram submetidos à análise estatística descritiva e à geoestatística. A melhor intensidade amostral para determinação do padrão de distribuição espacial foi dependente do atributo do solo estudado. Os teores de $\mathrm{P}$ e $\mathrm{K}^{+}$no solo apresentaram maior variabilidade espacial, enquanto os teores de argila, $\mathrm{Ca}^{2+}, \mathrm{Mg}^{2+}$ e valores de saturação por base (V) apresentaram menor variabilidade. Os teores de argila e os valores de V, na intensidade amostral com 100 pontos, foram os que melhor se correlacionaram com a produtividade.

PALAVRAS-CHAVE: geoestatística, agricultura de precisão, Zea mays.

\footnotetext{
${ }^{1}$ Doutorando em Agronomia (Produção Vegetal), FCAV/UNESP, Câmpus de Jaboticabal - SP, msalesrodrigues@gmail.com.

${ }^{2}$ Prof. Adjunto, Departamento de Solos, FCAV/UNESP, Câmpus de Jaboticabal - SP, cora@ fcav.unesp.br.

${ }^{3}$ Profa. Assistente Doutora, Departamento de Solos, FCAV/UNESP, Câmpus de Jaboticabal - SP, carol@ fcav.unesp.br.

Recebido pelo Conselho Editorial em: 11-4-2011

Aprovado pelo Conselho Editorial em: 3-5-2012
} 


\section{INTRODUCTION}

One of the determining factors for the practical application of the concepts of precision agriculture (PA) is related to the number of samples necessary to know, with accuracy, the spatial distribution pattern of soil attributes (CORÁ \& BERALDO, 2006). However, a large number of samples can raise costs relating to the analysis of soil attributes, thereby undermining the benefits of implementing the concepts of PA (KRAVCHENKO, 2003).

The accuracy of the maps of soil attributes is dependent on several factors, but primarily the spatial structure of the analyzed variables (MUELLER et al., 2001), therefore, is dependent on the sampling intensity used to be captured correctly. In this sense, THOMPSON et al. (2004) found that the spatial structure of the soil $\mathrm{K}^{+}$and $\mathrm{P}$ content were changed when the sampling intensity was modified. The authors noted that the sampling intensity of 0.20 samples per hectare the adjusted model for $\mathrm{K}^{+}$and $\mathrm{P}$ was the exponential, reaching values of 485 and $228 \mathrm{~m}$, respectively, whereas for the sample intensity of 0.40 samples per hectare the spherical model was adjusted and the ranges were 301 and $299 \mathrm{~m}$ for $\mathrm{K}^{+}$and $\mathrm{P}$, respectively.

The definition of sample intensity might depend on the evaluated attribute, since different soil properties may require different sampling intensities. This happens because some attributes suffer greater change in its spatial distribution pattern than others, mainly due to soil management. For example, the spatial variability of of soil $\mathrm{P}$ and $\mathrm{K}^{+}$content is most affected by soil management in relation to other chemical attributes, mainly due to those fertilizer nutrients contained in the lines seeding.

MALLARINO \& WITTRY (2004), when studying strategies for more efficient soil sampling approach in eight fields of agricultural production in the U.S., found that for all the strategies investigated, lower efficiency in the samples was for $\mathrm{P}$ and $\mathrm{K}^{+}$as compared with $\mathrm{pH}$ and organic matter (OM). In agreement with these results, SOUZA et al. (2006) found that it would be necessary a larger sample size to determine the spatial distribution patterns for $\mathrm{P}$ and $\mathrm{K}^{+}$compared to those required for $\mathrm{pH}$, organic matter and eutroferric Red Latosol clay under cultivation of sugar cane.

However, the definition of sampling intensity, based on knowledge of the spatial variability of soil attributes, is not sufficient for the decision making in the planning of crops. It is also necessary to verify that the data related to soil properties, obtained in a given intensity, were correlated with data from crop yield; therefore, to carry out the planning and commercial fields of scientific experiments it is necessary to know both the spatial variability of soil and plant attributes (REICHERT et al., 2008).

Based on the foregoing, the hypothesis of this study is that the spatial distribution of soil attributes change with the intensity of soil sampling and consequently affects the understanding of cause and effect relationships between the spatial distribution of crop productivity and the soil properties. Therefore, the study aimed to determine the spatial distribution of soil attributes, using four soil sampling intensity and corn yield, and see how the intensity of soil sampling interfere in understanding the relationship of cause and effect between soil properties and corn yield.

\section{MATERIAL AND METHODS}

The experiment was conducted in Jaboticabal, state of São Paulo (SP), in Brazil (21 $14^{\circ} 05^{\prime \prime S}$, $48^{\circ} 17^{\prime} 09^{\prime \prime} \mathrm{W}$ and altitude of $613 \mathrm{~m}$ ). Climatologically the area belongs to the tropical zone/megatermal or Köeppen Aw (tropical climate with dry winter and average temperature of the warmest month above $18{ }^{\circ} \mathrm{C}$ ). The average annual rainfall is $1,417 \mathrm{~mm}$, with annual distribution concentration in the period from October to March and on the dry period from April to September. The experimental area is classified as Rhodic Hapludox, clayey texture, soft wavy relief, with an average slope of $5 \%$. 
For 10 years, the experimental area has a corn crop in the summer using the no-tillage system and it remains fallow during the winter. Before sowing of the summer crop, a spontaneous vegetation desiccation is performed with non-selective herbicides.

In crop year 2007/2008, it was seeded the Syngent triple hybrid Master on 12/05/2007, aiming a density of 65,000 plants $\mathrm{ha}^{-1}$. The recommendations of fertilizers and sowing coverage were based on the results of chemical analysis of soil, according to RAIJ et al. (1997). At the time of sowing, it was applied $30 \mathrm{~kg}$ of $\mathrm{N}, 70 \mathrm{~kg}$ of $\mathrm{P}_{2} \mathrm{O}_{5}$ and $50 \mathrm{~kg}$ of $\mathrm{K}_{2} \mathrm{O}$ per ha. In coverage, it was applied $100 \mathrm{~kg} \mathrm{ha}^{-1}$ of $\mathrm{N}$ when the plants presented four to six pairs of fully developed leaves. Fertilization was performed conventionally, i.e., considering the average need of even input application in the area.

Data were collected following a sampling grid containing 100 points referenced according to coordinates $\mathrm{X}$ and $\mathrm{Y}$. The points were arranged at equidistant intervals, from $10 \mathrm{~m}$ in the direction of the rows of the crop ( $\mathrm{Y}$ coordinate), along with four $250 \mathrm{~m}$-long parallel transects, spaced $4.5 \mathrm{~m}$ (X coordinate), forming a rectangle with four columns and 25 rows. The cell sample was composed of five lines of $10 \mathrm{~m}$, totalizing $45 \mathrm{~m}^{2}$ each, considering the point referenced as the center of the cell (Figure 1).

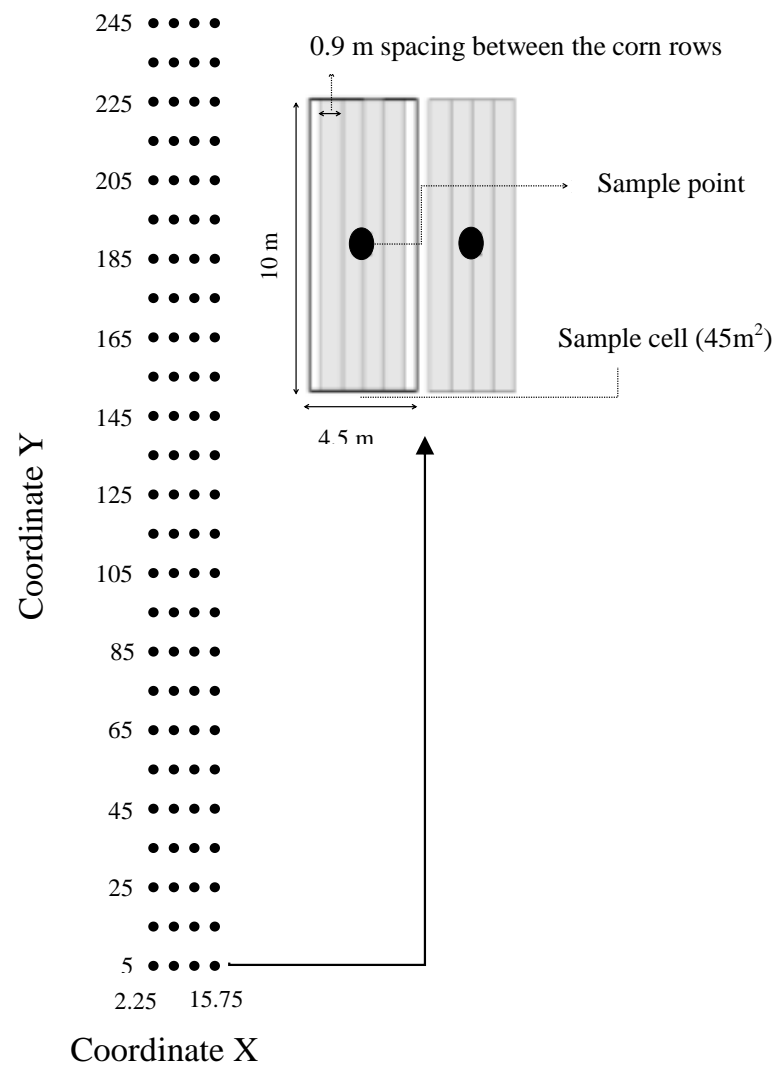

FIGURE 1. Sampling scheme of soil attributes and corn yield in a Rhodic Hapludox under notillage system.

The corn harvest was performed 151 days after sowing, using a mechanical harvester of plots, which allows the harvest of a row of corn at a time. Thus, in each cell sample was harvested five lines of $10 \mathrm{~m}$ of corn plants, and the mass of grains was considered as the productivity of the cell. The grain moisture was standardized at $13 \%$ to estimate the yield $\left(\mathrm{Mg} \mathrm{ha}^{-1}\right)$.

After the corn harvest, the soil sampling was performed, using a Dutch auger, in the layers 0 to 0.1 and 0.1 to $0.2 \mathrm{~m}$ deep, collecting five soil sub-samples to compose a representative composite sample, one sub-sample collected in the center of the cell (referenced point) and the other in the four cardinal points, spaced $2 \mathrm{~m}$ from the midpoint. It was measured the clay content (CAMARGO et al., 1986), $\mathrm{pH}, \mathrm{P}, \mathrm{K}^{+}, \mathrm{Ca}^{2+}, \mathrm{Mg}^{2+}$ and $\mathrm{OM}$ in the samples, according to the procedures described 
by RAIJ et al. (2001). Then, it was calculated the soil cation exchange capacity (CEC) and percent of soil bases saturation (V).

The sampling intensities were established by elimination of intermediate sample points, starting from the highest intensity of the sampling grid, i.e., the sample grid with 100 points spaced 10 meters as Y coordinate and 4.5 meters as X coordinate. Thus, obtaining data sets with 100; 75; 50 and 25 sampling points (Figure 2). Regarding the intensity of 75 points, it was taken points every 40 meters in $\mathrm{Y}$ direction, starting with the distance 25 in coordinate $\mathrm{Y}$. Thus forming seven sets of points spaced $20 \mathrm{~m}$ apart according to the coordinate $\mathrm{Y}$. In the sample grids of 50 and 25 points, the sampling points were spaced 20 to $40 \mathrm{~m}$ in Y direction, respectively (Figure 2).

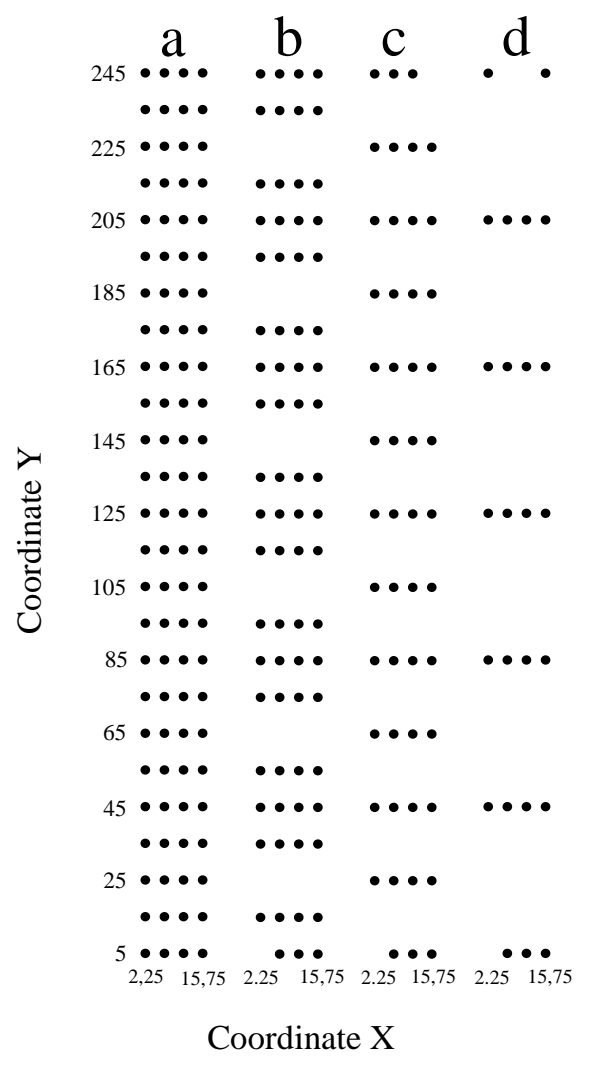

FIGURE 2. Model of sampling distribution for different sampling intensities: a (100 points), b (75 points), c (50 points) and d (25 points).

The data set, obtained from each sampling plan, was submitted to descriptive statistical analysis to determine the average, maximum and minimum values, coefficient of variation (C.V.), asymmetry and kurtosis coefficients and data frequency distribution. To test the hypothesis of normality of the data, it was used the SHAPIRO \& WILK (1965) test.

To estimate the spatial dependence between samples, as well as identify whether the changes were systematic or random, it was used semivariogram models. The selection of models was based on the smallest residual sum of squares (RSS) and better coefficient of determination $\left(\mathrm{R}^{2}\right)$. The semivariograms were validated by the cross validation method, noting isotropy in all adjusted models, indicating that the pattern of spatial variability structure is the same in all directions.

To analyze the degree of spatial dependence it was used the classification of CAMBARDELLA et al. (1994), which considers the strong spatial dependence semivariograms having nugget effect equal to $25 \%$ of the sill; moderate spatial dependence when the nugget effect is between 25 and $75 \%$ and low spatial dependence when the nugget effect is greater than $75 \%$.

Seeking to spatially correlate corn yield and soil attributes, it was estimated the crossed semivariogram. It was used the corn yield as a dependent variable and soil attributes as a covariate. The soil variables were used to estimate the cross semivariogram only when presented simple 
semivariograms, i.e., presented spatial dependence (VIEIRA, 2000). It was selected the cross semivariogram which presented its series of points distributed only in one quadrant, denoting thus a reliable aspect between yield and soil attributes (MEGDA et al., 2008), since the cross semivariogram presenting their number of points in more than one quadrant are considered spatial correlation indefinite (CAMARGO et al., 2008).

\section{RESULTS AND DISCUSSION}

The results show that average values for clay were similar between different sampling intensities (Table 1). Based on the C.V. classification, suggested by PIMENTEL-GOMEZ \& GARCIA (2002), we observed a low variability (C.V. < 10\%) for clay depths 0 to 0.1 and 0.1 to $0.2 \mathrm{~m}$ for all sample intensities studied (Table 1). Similar results were obtained by KITAMURA et al. (2007) to study the variability of attributes of a Rhodic Hapludox under no-tillage system. However, MELLO et al. (2006) found average variability for clay in a Eutroferric red latosol under cultivation of sugar cane.

TABLE 1. Results of the descriptive statistics and semivariogram parameters of clay content $\left(\mathrm{g} \mathrm{kg}^{-1}\right)$, from 0 to 0.1 and from 0.1 to $0.2 \mathrm{~m}$ depths, for four sampling intensities in a Rhodic Hapludox under no-tillage system.

\begin{tabular}{|c|c|c|c|c|c|c|c|c|}
\hline \multirow[b]{3}{*}{ Statistics } & \multicolumn{8}{|c|}{ Number of Sampling Points } \\
\hline & 100 & 75 & 50 & 25 & 100 & 75 & 50 & 25 \\
\hline & \multicolumn{4}{|c|}{0 to $0.1 \mathrm{~m}$} & \multicolumn{4}{|c|}{0.1 to $0.2 \mathrm{~m}$} \\
\hline Average & 333 & 333 & 333 & 333 & 355 & 355 & 354 & 354 \\
\hline Medium & 335 & 335 & 334 & 334 & 356 & 356 & 356 & 356 \\
\hline Minimum & 288 & 288 & 288 & 304 & 314 & 314 & 316 & 316 \\
\hline Maximum & 373 & 366 & 373 & 359 & 391 & 387 & 391 & 387 \\
\hline C.V. & 6 & 5 & 6 & 4 & 6 & 5 & 6 & 6 \\
\hline Asymmetry coefficient & -0.17 & -0.18 & -0.18 & -0.29 & -0.12 & -0.08 & 0.04 & 0.05 \\
\hline Kurtosis coefficient & -0.53 & -0.61 & -0.15 & 0.12 & -0.87 & -0.91 & -0.91 & -0.92 \\
\hline $\mathrm{P}<\mathrm{W}$ & 0.287 & 0.340 & 0.791 & 0.801 & 0.047 & 0.073 & 0.152 & 0.216 \\
\hline Normality & $\mathrm{N}$ & $\mathrm{N}$ & $\mathrm{N}$ & $\mathrm{N}$ & $\mathrm{N}$ & $\mathrm{N}$ & $\mathrm{N}$ & $\mathrm{N}$ \\
\hline Model & Gau & Exp & Exp & & Sph & Exp & Gau & \\
\hline $\mathrm{C}_{0}$ & 159.0 & 111.8 & 150.5 & & 229.6 & 236.4 & 269.7 & \\
\hline $\mathrm{C}_{0}+\mathrm{C}$ & 356.0 & 355.3 & 348.3 & & 459.3 & 435.7 & 545.8 & \\
\hline Range (m) & 49 & 120 & 87 & & 121 & 148 & 121 & \\
\hline SDD & $\mathrm{M}$ & M & M & & $\mathrm{M}$ & M & M & \\
\hline $\mathrm{R}^{2}$ & 0.908 & 0.738 & 0.842 & & 0.824 & 0.599 & 0.793 & \\
\hline RSS & 6462 & 24903 & 6371 & & 18292 & 42980 & 35051 & \\
\hline
\end{tabular}

C.V.= Coefficient of variation $(\%) ; \mathrm{P}<\mathrm{W}=$ normality test result; $\mathrm{N}=$ Normal distribution $(\mathrm{P}<\mathrm{M}>0.01)$; Sph $=$ Spherical; Exp = Exponential; $\mathrm{Gau}=$ Gaussian; $\mathrm{C}_{0}=$ Nugget effect $; \mathrm{C}_{0}+\mathrm{C}=$ Sill; $\mathrm{SDD}=$ Spatial dependence degree; $\mathrm{M}=$ Moderate; RSS $=$ Residual sum of squares.

The values of the average and medium to the clay are close. Additionally, the coefficients of asymmetry and kurtosis are close to zero, indicating symmetric distributions (Table 1). Similar results were obtained by AMARO FILHO et al. (2007) in an Oxisol on a sampling grid of 100 points spaced $10 \mathrm{~m}$. The normality of the data for these attributes (Table 1) is confirmed by the result of the SHAPIRO \& WILK (1965) test.

The clay attribute showed spatial dependence for all sample intensities, with the exception of sampling intensity with 25 points. This happened because the spacing adopted in intensity with 25 points was not enough to capture the spatial dependence of clay. The Gaussian model was adjusted for the clay data at the depth of 0 to $0.1 \mathrm{~m}$ in the sampling intensity with 100 points, and the exponential model was adjusted with 75 and 50 sampling points. For the depth of 0.1 to $0.2 \mathrm{~m}$, it was fitted the spherical model for the sample intensity with 100 points, exponential for the one with 75 points and Gaussian to the one with 50 points (Table 1). KITAMURA et al. (2007), working with Rhodic Hapludox under no-tillage system and with a sample grid of 75 points spaced $10 \mathrm{~m}$, adjusted the spherical model for clay depths 0 to 0.1 and 0.1 to $0.2 \mathrm{~m}$. 
It was observed that, with the change in sample intensity, the clay showed variation in the value range from $49 \mathrm{~m}$ in the intensity of sampling with 100 points to $120 \mathrm{~m}$ when using 75 points, to the depth of 0 to $0.1 \mathrm{~m}$ (Table 1). This indicates that the choice of sampling intensity can alter the results of the spatial structure of the attribute clay and that the choice of sampling intensity is crucial for understanding the spatial distribution pattern of clay. According to the classification of CAMBARDELLA et al. (1994), the clay showed moderate spatial dependence (Table 1) for the sample intensities studied. Therefore, the sampling intensity did not alter the spatial dependence degree of clay. KITAMURA et al. (2007) observed moderate spatial dependence for clay while MELLO et al. (2006) found strong spatial dependence.

Based on the classification by the C.V., the attribute phosphorus showed high variability in all sample intensities and depths studied (Table 2). In sample intensities of 100 and 75 points, data did not present normality, while the intensities 50 and 25 data presented normality. This may have occurred because the withdrawal of points is possible if you have eliminated extreme points, but real, that influenced the data normality.

TABLE 2. Results of the descriptive statistics and semivariogram parameters of soil phosphorus content $\left(\mathrm{mg} \mathrm{dm}^{-3}\right.$ ), from 0 to 0.1 and from 0.1 to $0.2 \mathrm{~m}$ depths, for four sampling intensities in a Rhodic Hapludox under no-tillage system.

\begin{tabular}{|c|c|c|c|c|c|c|c|c|}
\hline \multirow[b]{3}{*}{ Statistics } & \multicolumn{8}{|c|}{ Number of Sampling Points } \\
\hline & 100 & 75 & 50 & 25 & 100 & 75 & 50 & 25 \\
\hline & \multicolumn{4}{|c|}{$0-0.1 \mathrm{~m}$} & \multicolumn{4}{|c|}{$0.1-0.2 \mathrm{~m}$} \\
\hline Average & 33 & 33 & 32 & 30 & 21 & 21 & 20 & 20 \\
\hline Medium & 31 & 30 & 31 & 27 & 20 & 19 & 19 & 16 \\
\hline Minimum & 8 & 8 & 8 & 8 & 7 & 8 & 7 & 8 \\
\hline Maximum & 67 & 67 & 64 & 60 & 46 & 46 & 42 & 42 \\
\hline C.V. & 48 & 46 & 50 & 47 & 45 & 47 & 45 & 52 \\
\hline Asymmetry coefficient & 0.46 & 0.51 & 0.33 & 0.32 & 0.73 & 0.86 & 0.58 & 0.76 \\
\hline Kurtosis coefficient & -0.78 & -0.67 & -0.97 & -0.83 & -0.04 & 0.00 & -0.55 & -0.61 \\
\hline $\mathrm{P}<\mathrm{W}$ & 0.001 & 0.007 & 0.044 & 0.512 & 0.000 & 0.000 & 0.024 & 0.014 \\
\hline Normality & $\mathrm{N}-\mathrm{N}$ & $\mathrm{N}-\mathrm{N}$ & $\mathrm{N}$ & $\mathrm{N}$ & $\mathrm{N}-\mathrm{N}$ & $\mathrm{N}-\mathrm{N}$ & $\mathrm{N}$ & $\mathrm{N}$ \\
\hline Model & Exp & Exp & & & Exp & Exp & & Gau \\
\hline $\mathrm{C}_{0}$ & 117.7 & 116.8 & & & 60.5 & 53.5 & & 60.4 \\
\hline $\mathrm{C}_{0}+\mathrm{C}$ & 255.3 & 246.9 & & & 92.123 & 107.1 & & 120.9 \\
\hline Range (m) & 20 & 16 & & & 36 & 47 & & 22 \\
\hline SDD & M & $\mathrm{M}$ & & & M & $\mathrm{M}$ & & $\mathrm{M}$ \\
\hline $\mathrm{R}^{2}$ & 0.579 & 0.480 & & & 0.503 & 0.768 & & 0.584 \\
\hline RSS & 2006 & 2835 & & & 358 & 347 & & 1195 \\
\hline
\end{tabular}

C.V.= Coefficient of variation $(\%) ; \mathrm{P}<\mathrm{W}=$ normality test result; $\mathrm{N}=$ Normal distribution $(\mathrm{P}<\mathrm{M}>0.01) ; \quad \mathrm{N}-\mathrm{N}=\mathrm{Non}-\mathrm{normal}$ distribution $(\mathrm{P}<\mathrm{M}<0.01)$; Exp = Exponential; $\mathrm{Gau}=$ Gaussian; $\mathrm{C}_{0}=$ Nugget effect $\mathrm{C}_{0}+\mathrm{C}=$ Sill; $\mathrm{SDD}=$ Spatial dependence degree; $\mathrm{M}=$ Moderate; RSS = Residual sum of squares.

The exponential model was fitted for the P levels at depths from 0 to 0.1 and 0.1 to $0.2 \mathrm{~m}$ in the sample intensities with 100 and 75 points. At depth of 0.1 to $0.2 \mathrm{~m}$, the Gaussian model was adjusted when using 25 points (Table 2). Similar results were obtained by CAVALCANTE et al. (2007a), working with Hipodystrophic red latosol under no-tillage system and sampling grid of 64 points spaced $2 \mathrm{~m}$ when fitted to the exponential model for $\mathrm{P}$ at depth 0 to $0.1 \mathrm{~m}$ and spherical for the depth of 0.1 to $0.2 \mathrm{~m}$. In the present study, the range of values for $\mathrm{P}$ across the with sampling intensity, with the largest variation observed when using the sampling intensity with 75 points $(47 \mathrm{~m})$ compared with that one with 25 points $(22 \mathrm{~m})$ at depth of 0.1 to $0.2 \mathrm{~m}$ (Table 3 ).

As for $\mathrm{P}$, high variability was also observed in the $\mathrm{K}^{+}$contents (Table 3 ). High variability for the soil $\mathrm{K}^{+}$were also found by CORÁ et al. (2004) in an Eutroferric red latosol under cultivation of sugar cane and by MACHADO et al. (2007) in an Red Latosol under conventional tillage. 
TABLE 3. Results of the descriptive statistics and semivariogram parameters of soil potassium content $\left(\mathrm{mmol}_{\mathrm{c}} \mathrm{dm}^{-3}\right)$ from 0 to 0.1 and from 0.1 to $0.2 \mathrm{~m}$ depths, for four sampling intensities in a Rhodic Hapludox under no-tillage system.

\begin{tabular}{|c|c|c|c|c|c|c|c|c|}
\hline \multirow[b]{3}{*}{ Statistics } & \multicolumn{8}{|c|}{ Number of Sampling Points } \\
\hline & 100 & 75 & 50 & 25 & 100 & 75 & 50 & 25 \\
\hline & \multicolumn{4}{|c|}{0 to $0.1 \mathrm{~m}$} & \multicolumn{4}{|c|}{01 to $0.2 \mathrm{~m}$} \\
\hline Average & 1.90 & 1.92 & 1.96 & 1.94 & 1.39 & 1.37 & 1.37 & 1.38 \\
\hline Medium & 1.90 & 1.80 & 1.90 & 1.80 & 1.30 & 1.30 & 1.30 & 1.30 \\
\hline Minimum & 0.90 & 0.90 & 1.00 & 1.30 & 0.80 & 0.80 & 0.80 & 0.80 \\
\hline Maximum & 3.60 & 3.60 & 3.60 & 3.50 & 2.40 & 2.20 & 2.10 & 2.00 \\
\hline C.V. & 30 & 30 & 30 & 28 & 26 & 26 & 24 & 24 \\
\hline Asymmetry coefficient & 0.81 & 0.67 & 1.19 & 1.38 & 0.41 & 0.34 & 0.31 & 0.38 \\
\hline Kurtosis coefficient & 0.79 & 0.45 & 1.48 & 1.79 & -0.39 & -0.69 & -0.64 & -0.57 \\
\hline $\mathrm{P}<\mathrm{W}$ & $\mathrm{N}-\mathrm{N}$ & $\mathrm{N}-\mathrm{N}$ & $\mathrm{N}-\mathrm{N}$ & $\mathrm{N}-\mathrm{N}$ & $\mathrm{N}-\mathrm{N}$ & $\mathrm{N}-\mathrm{N}$ & $\mathrm{N}-\mathrm{N}$ & $\mathrm{N}-\mathrm{N}$ \\
\hline Normality & 0.00 & 0.00 & 0.00 & 0.00 & 0.00 & 0.00 & 0.00 & 0.00 \\
\hline Model & & Sph & & & $\operatorname{Exp}$ & Exp & & \\
\hline $\mathrm{C}_{0}$ & & 0.145 & & & 0.051 & 0.046 & & \\
\hline $\mathrm{C}_{0}+\mathrm{C}$ & & 0.265 & & & 0.118 & 0.118 & & \\
\hline Range (m) & & 9 & & & 18 & 17 & & \\
\hline SDD & & $\mathrm{M}$ & & & $\mathrm{M}$ & $\mathrm{M}$ & & \\
\hline $\mathrm{R}^{2}$ & & 0.234 & & & 0.478 & 0.301 & & \\
\hline RSS & & $3.16 \mathrm{E}-03$ & & & $6.76 \mathrm{E}-04$ & $2.02 \mathrm{E}-03$ & & \\
\hline
\end{tabular}

C.V.= Coefficient of variation $(\%) ; \mathrm{P}<\mathrm{W}=$ normality test result; $\mathrm{N}-\mathrm{N}=$ Non-normal distribution $(\mathrm{P}<\mathrm{M}<0.01) ;$ Sph $=$ Spherical; Exp $=$ Exponential $; \mathrm{C}_{0}=$ Nugget effect $; \mathrm{C}_{0}+\mathrm{C}=$ Sill $; \mathrm{SDD}=$ Spatial dependence degree $; \mathrm{M}=$ Moderate; $\mathrm{RSS}=$ Residual sum of squares .

The high variability for the soil $\mathrm{P}$ content may be related to their low mobility in soil (MACHADO et al., 2007). On the other hand, the variability of the $\mathrm{K}^{+}$in soil due to not only to lines fertilization, but also the location of the plants because the $\mathrm{K}^{+}$does not form organic compounds in the plant tissue and is easily transported from shoots to soil after a rain. Thus, theoretically, $\mathrm{K}^{+}$tends to concentrate near the stem of each plant, decreasing concentration as it move away (CARVALHO et al., 2002).

The spherical model was adjusted for the $\mathrm{K}$ in the soil at the depth of 0 to $0.1 \mathrm{~m}$ and the sampling intensity with 75 points. At the depth of 0.1 to $0.2 \mathrm{~m}$, it was fitted the exponential model to the sample intensities with 100 and 75 points (Table 3). CAVALCANTE et al. (2007b), working with a sample grid of 64 points spaced $2 \mathrm{~m}$, fitted the spherical model for the soil $\mathrm{K}^{+}$content at depths of 0 to 0.1 and 0.1 to $0.2 \mathrm{~m}$. CORÁ et al. (2004), in a sample grid of 421 points spaced $50 \mathrm{~m}$, set the exponential model for soil $\mathrm{K}^{+}$content at depths of 0.1 to $0.2 \mathrm{~m}$ and 0.6 to $0.8 \mathrm{~m}$.

The results obtained with the adjusting of the data to clay, $\mathrm{P}$ and $\mathrm{K}^{+}$contents semivariograms models indicate that the choice of the experimental model of semivariogram is dependent not only of the evaluated attribute, but also the sampling rate, i.e., to the same attribute you can adjust different experimental models and obtain different values of the range varying the sampling intensity. These results are accordingly to those reported by THOMPSON et al. (2004) who also observed that, when used 0.2 samples per ha, the data for $\mathrm{P}$ and $\mathrm{K}^{+}$content were adjusted to the exponential model, and when used 0.4 samples per ha, the data were adjusted to the spherical model.

The content of soil organic matter (OM) showed C.V. values between 13 and $16 \%$ for sample intensities and depths studied, classified as medium variability (Table 4), in accordance with the results obtained by CORÁ et al. (2004). The data presented normality in all intensities and depths studied (Table 4) and no spatial dependence. One hypothesis for this fact is that the continuous deposition of plant residues on the soil of the experimental area during the 10 years that the soil has been used under tillage provided certain homogenization of the levels of soil OM, causing a random pattern of distribution spatial levels of soil OM. 
TABLE 4. Results of the descriptive statistics of soil organic matter content $\left(\mathrm{g} \mathrm{dm}^{-3}\right)$, from 0 to 0.1 and from 0.1 to $0.2 \mathrm{~m}$ depths, for four sampling intensities in a Rhodic Hapludox under no-tillage system.

\begin{tabular}{|c|c|c|c|c|c|c|c|c|}
\hline \multirow[b]{3}{*}{ Statistics } & \multicolumn{8}{|c|}{ Number of Sampling Points } \\
\hline & 100 & 75 & 50 & 25 & 100 & 75 & 50 & 25 \\
\hline & \multicolumn{4}{|c|}{0 to $0.1 \mathrm{~m}$} & \multicolumn{4}{|c|}{0.1 to $0.2 \mathrm{~m}$} \\
\hline Average & 17 & 17 & 17 & 17 & 14 & 14 & 14 & 14 \\
\hline Medium & 17 & 17 & 17 & 17 & 14 & 14 & 14 & 14 \\
\hline Minimum & 11 & 11 & 11 & 11 & 8 & 8 & 8 & 11 \\
\hline Maximum & 22 & 22 & 22 & 22 & 18 & 18 & 18 & 18 \\
\hline C.V. & 13 & 14 & 15 & 16 & 15 & 15 & 14 & 14 \\
\hline Asymmetry coefficient & 0.10 & 0.22 & -0.04 & -0.03 & -0.32 & -0.34 & -0.14 & 0.12 \\
\hline Kurtosis coefficient & 0.28 & 0.13 & 0.23 & -0.12 & 0.11 & -0.27 & 0.31 & -0.91 \\
\hline $\mathrm{P}<\mathrm{W}$ & 0.043 & 0.108 & 0.242 & 0.779 & 0.018 & 0.038 & 0.145 & 0.251 \\
\hline Normality & $\mathrm{N}$ & $\mathrm{N}$ & $\mathrm{N}$ & $\mathrm{N}$ & $\mathrm{N}$ & $\mathrm{N}$ & $\mathrm{N}$ & $\mathrm{N}$ \\
\hline
\end{tabular}

C.V.= Coefficient of variation (\%); $\mathrm{P}<\mathrm{W}=$ normality test result; $\mathrm{N}-\mathrm{N}=$ Non-normal distribution $(\mathrm{P}<\mathrm{M}<0.01)$.

Among the soil chemical properties, the lowest value of $\mathrm{CV}$ was found for $\mathrm{pH}$ (between 10 and 13\%) in the sample intensities and depths studied, getting close to the limit of the class of low variability (C.V. < 10\%) (Table 5). Similar results were obtained by CORÁ et al. (2004), when worked with an eutroferric red Latosol under cultivation of sugar cane. It is expected the occurrence of lower value of $\mathrm{CV}$ for $\mathrm{pH}$, since their values vary within a narrow range (GOMES et al., 2008). Agreeing with COELHO et al. (2003), the C.V. of pH can not be compared with those of other attributes because it is measured in logarithmic scale.

A tendency was observed in the data for soil $\mathrm{pH}$ at both depths studied, because the semivariogram, when fitted with the original data, grew without limits for all calculated values of $h$ (distance of samples), indicating that the size of the field sampled was not enough to display all the variance (VIEIRA, 2000). The tendency has been removed by the method of trend surface proposed by DAVIS (1973).

TABLE 5. Results of the descriptive statistics and semivariogram parameters of soil $\mathrm{pH}$, from 0 to 0.1 and from 0.1 to $0.2 \mathrm{~m}$ depths, for four sampling intensities in a Rhodic Hapludox under no-tillage system.

\begin{tabular}{|c|c|c|c|c|c|c|c|c|}
\hline \multirow[b]{3}{*}{ Statistics } & \multicolumn{8}{|c|}{ Number of Sampling Points } \\
\hline & 100 & 75 & 50 & 25 & 100 & 75 & 50 & 25 \\
\hline & \multicolumn{4}{|c|}{0 to $0.1 \mathrm{~m}$} & \multicolumn{4}{|c|}{0.1 to $0.2 \mathrm{~m}$} \\
\hline Average & 4.8 & 4.8 & 4.8 & 4.8 & 4.8 & 4.8 & 4.7 & 4.8 \\
\hline Medium & 4.7 & 4.7 & 4.7 & 4.7 & 4.6 & 4.7 & 4.5 & 4.6 \\
\hline Minimum & 3.9 & 3.9 & 3.9 & 3.9 & 4.0 & 4.0 & 4.0 & 4.0 \\
\hline Maximum & 6.4 & 6.4 & 6.4 & 6.4 & 6.3 & 6.3 & 6.3 & 6.3 \\
\hline $\mathrm{CV}$ & 11 & 11 & 10 & 12 & 11 & 12 & 11 & 13 \\
\hline Asymmetry coefficient & 1.01 & 1.06 & 1.17 & 1.49 & 1.13 & 1.17 & 1.28 & 1.39 \\
\hline Kurtosis coefficient & 1.20 & 1.23 & 2.50 & 2.88 & 1.02 & 1.01 & 1.88 & 1.54 \\
\hline $\mathrm{P}<\mathrm{W}$ & 0.00 & 0.00 & 0.00 & 0.00 & 0.00 & 0.00 & 0.00 & 0.00 \\
\hline Normality & $\mathrm{N}-\mathrm{N}$ & $\mathrm{N}-\mathrm{N}$ & $\mathrm{N}-\mathrm{N}$ & $\mathrm{N}-\mathrm{N}$ & $\mathrm{N}-\mathrm{N}$ & $\mathrm{N}-\mathrm{N}$ & $\mathrm{N}-\mathrm{N}$ & $\mathrm{N}-\mathrm{N}$ \\
\hline Model & Gau & Gau & Gau & Gau & Gau & Gau & Gau & Gau \\
\hline $\mathrm{C}_{0}$ & 0.039 & 0.038 & 0.032 & 0.018 & 0.025 & 0.025 & 0.052 & 0.034 \\
\hline $\mathrm{C}_{0}+\mathrm{C}$ & 0.120 & 0.098 & 0.100 & 0.218 & 0.144 & 0.144 & 0.182 & 0.284 \\
\hline Range (m) & 12 & 10 & 10 & 15 & 13 & 14 & 12 & 13 \\
\hline SDD & $\mathrm{M}$ & M & $\mathrm{M}$ & $\mathrm{F}$ & $\mathrm{F}$ & $\mathrm{F}$ & $\mathrm{M}$ & $\mathrm{F}$ \\
\hline $\mathrm{R}^{2}$ & 0.445 & 0.552 & 0.312 & 0.686 & 0.683 & 0.620 & 0.453 & 0.603 \\
\hline RSS & $2.35 \mathrm{E}-03$ & $9.67 \mathrm{E}-04$ & $2.37 \mathrm{E}-03$ & $8.67 \mathrm{E}-03$ & $2.31 \mathrm{E}-03$ & $3.71 \mathrm{E}-03$ & $7.05 \mathrm{E}-03$ & 0.0175 \\
\hline
\end{tabular}


For soil $\mathrm{pH}$, it was adjusted linear trend surfaces in $\mathrm{Y}$ in sampling intensity with 100 points and at both depths studied. In sampling intensity with 75 points, it was adjusted linear trend surfaces in $\mathrm{Y}$ and $\mathrm{X}$, at the depth of 0.0 to $0.1 \mathrm{~m}$ and linear in the $\mathrm{Y}$ at the depth of 0.1 to $0.2 \mathrm{~m}$. In sampling intensity with 50 points, it was adjusted the linear trend surface in $\mathrm{X}$ and $\mathrm{Y}$ to the depth of 0.0 to $0.1 \mathrm{~m}$ and linear straight in $\mathrm{Y}$ at the depth of 0.1 to $0.2 \mathrm{~m}$. For the intensity with 25 points there was no need to adjust trend surface. After removal of the trend, it was possible to adjust the $\mathrm{pH}$ to the Gaussian model for depths and the soil sample intensities studied (Table 5). Contrary results were obtained by CORÁ et al. (2004) that fitted the spherical model for soil $\mathrm{pH}$.

The levels of $\mathrm{Ca}^{2+}$ (Table 6), $\mathrm{Mg}^{2+}$ (Table 7) and $\mathrm{V}$ (base saturation) (Table 8) were considered with high variability according to the classification by C.V. This occurs because of the non-uniform distribution of lime in the surface, which probably led to greater variability of these attributes in the experimental area.

Noting the variability of soil properties studied in this study, based on the C.V., it is possible to see that it is similar to the different tested sample intensities. These results are in accordance with those obtained by THOMPSON et al. (2004) that, by studying an area with predominant Red Alfisol under no-tillage system and with rotation of peanut-wheat-corn crops, it was found that the variability of the levels of $\mathrm{P}, \mathrm{K}^{+}, \mathrm{Ca}^{2+}$ and $\mathrm{Mg}^{2+}$ did not change when the intensity of sampling was $0.2,0.4$ and 1.0 sample per ha.

TABLE 6. Results of the descriptive statistics and semivariogram parameters of soil calcium content $\left(\mathrm{mmol}_{\mathrm{c}} \mathrm{dm}^{-3}\right)$ from 0 to 0.1 and from 0.1 to $0.2 \mathrm{~m}$ depths, for four sampling intensities in a Rhodic Hapludox under no-tillage system.

\begin{tabular}{|c|c|c|c|c|c|c|c|c|}
\hline \multirow[b]{3}{*}{ Statistics } & \multicolumn{8}{|c|}{ Number of Sampling Points } \\
\hline & 100 & 75 & 50 & 25 & 100 & 75 & 50 & 25 \\
\hline & \multicolumn{4}{|c|}{0 to $0.1 \mathrm{~m}$} & \multicolumn{4}{|c|}{0.1 to $0.2 \mathrm{~m}$} \\
\hline Average & 22 & 23 & 20 & 25 & 20 & 20 & 18 & 23 \\
\hline Medium & 15 & 15 & 14 & 11 & 12 & 13 & 10 & 12 \\
\hline Minimum & 3 & 3 & 4 & 5 & 3 & 3 & 3 & 4 \\
\hline Maximum & 152 & 152 & 152 & 152 & 150 & 129 & 129 & 129 \\
\hline C.V. & 125 & 123 & 133 & 142 & 126 & 118 & 135 & 142 \\
\hline Asymmetry coefficient & 3.17 & 2.89 & 3.82 & 2.69 & 3.17 & 2.62 & 3.55 & 2.56 \\
\hline Kurtosis coefficient & 10.35 & 8.71 & 15.51 & 6.83 & 11.08 & 7.07 & 12.95 & 5.68 \\
\hline $\mathrm{P}<\mathrm{W}$ & 0.00 & 0.00 & 0.00 & 0.00 & 0.00 & 0.00 & 0.00 & 0.00 \\
\hline Normality & $\mathrm{N}-\mathrm{N}$ & $\mathrm{N}-\mathrm{N}$ & $\mathrm{N}-\mathrm{N}$ & $\mathrm{N}-\mathrm{N}$ & $\mathrm{N}-\mathrm{N}$ & $\mathrm{N}-\mathrm{N}$ & $\mathrm{N}-\mathrm{N}$ & $\mathrm{N}-\mathrm{N}$ \\
\hline Model & Gau & Gau & Gau & Gau & Gau & Gau & Gau & \\
\hline $\mathrm{C}_{0}$ & 77.2 & 111.1 & 2.0 & 1.0 & 2.8 & 5.0 & 1.0 & \\
\hline $\mathrm{C}_{0}+\mathrm{C}$ & 413.1 & 428.8 & 582.4 & 1240.0 & 322.4 & 289.9 & 433.1 & \\
\hline Range (m) & 12 & 13 & 15 & 14 & 14 & 14 & 13 & \\
\hline SDD & $\mathrm{F}$ & $\mathrm{M}$ & $\mathrm{F}$ & $\mathrm{F}$ & $\mathrm{F}$ & $\mathrm{F}$ & $\mathrm{F}$ & \\
\hline $\mathrm{R}^{2}$ & 0.495 & 0.285 & 0.650 & 0.666 & 0.736 & 0.496 & 0.600 & \\
\hline RSS & 41606 & 66272 & 112983 & 472368 & 25234 & 48549 & 102992 & \\
\hline
\end{tabular}

C.V.= Coefficient of variation (\%); $\mathrm{P}<\mathrm{W}=$ normality test result; $\mathrm{N}-\mathrm{N}=$ Non-normal distribution $(\mathrm{P}<\mathrm{M}<0.01) ; \mathrm{Gau}=\mathrm{Gaussian} ; \mathrm{C}_{0}=$ Nugget effect; $\mathrm{C}_{0}+\mathrm{C}=$ Sill; $\mathrm{SDD}=$ Spatial dependence degree; $\mathrm{M}=$ Moderate; $\mathrm{F}=$ Strong; $\mathrm{RSS}=$ Residual sum of squares.

As for $\mathrm{pH}$ values, there was a trend in the data for $\mathrm{Ca}^{2+}$ and $\mathrm{Mg}^{2+}$ and $\mathrm{V}$ values and corn yield at both depths studied. In sampling intensity with 100 points, linear trend surfaces were adjusted in

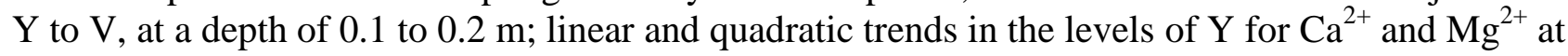
both depths; linear in $\mathrm{X}$ and in $\mathrm{Y}$ for values of $\mathrm{V}$ and corn yield, 0 to $0.1 \mathrm{~m}$ depth. For a sampling rate of 75 points, it was adjusted the linear trend surface in the values of $\mathrm{Y}$ to $\mathrm{V}$ at the depth of 0.1 to $0.2 \mathrm{~m}$; linear and quadratic $\mathrm{Y}$ for $\mathrm{Ca}^{2+}$ and $\mathrm{Mg}^{2+}$ in both depths; linear in $\mathrm{X}$ and $\mathrm{Y}$ for values of $\mathrm{V}$ at the depths of 0 to $0.1 \mathrm{~m}$. For the intensity with 25 points there was no need to adjust trend surface. 
TABLE 7. Results of the descriptive statistics and semivariogram parameters of soil magnesium content $\left(\mathrm{mmol}_{\mathrm{c}} \mathrm{dm}^{-3}\right)$, from 0 to 0.1 and from 0.1 to $0.2 \mathrm{~m}$ depths, for four sampling intensities in a Rhodic Hapludox under no-tillage system.

\begin{tabular}{|c|c|c|c|c|c|c|c|c|}
\hline \multirow[b]{3}{*}{ Statistics } & \multicolumn{8}{|c|}{ Number of Sampling Points } \\
\hline & 100 & 75 & 50 & 25 & 100 & 75 & 50 & 25 \\
\hline & \multicolumn{4}{|c|}{0 to $0.1 \mathrm{~m}$} & \multicolumn{4}{|c|}{0.1 to $0.2 \mathrm{~m}$} \\
\hline Average & 11 & 12 & 10 & 13 & 10 & 10 & 8 & 12 \\
\hline Medium & 7 & 7 & 7 & 6 & 5 & 5 & 4 & 5 \\
\hline Minimum & 2 & 2 & 2 & 3 & 1 & 1 & 1 & 1 \\
\hline Maximum & 69 & 69 & 69 & 69 & 68 & 68 & 68 & 68 \\
\hline C.V. & 126 & 128 & 141 & 148 & 146 & 143 & 165 & 163 \\
\hline Asymmetry coefficient & 2.78 & 2.53 & 3.55 & 2.44 & 2.82 & 2.55 & 3.57 & 2.47 \\
\hline Kurtosis coefficient & 7.07 & 5.54 & 11.97 & 4.57 & 7.25 & 5.66 & 12.12 & 4.73 \\
\hline $\mathrm{P}<\mathrm{W}$ & 0.00 & 0.00 & 0.00 & 0.00 & 0.00 & 0.00 & 0.00 & 0.00 \\
\hline Normality & $\mathrm{N}-\mathrm{N}$ & $\mathrm{N}-\mathrm{N}$ & $\mathrm{N}-\mathrm{N}$ & $\mathrm{N}-\mathrm{N}$ & $\mathrm{N}-\mathrm{N}$ & $\mathrm{N}-\mathrm{N}$ & $\mathrm{N}-\mathrm{N}$ & $\mathrm{N}-\mathrm{N}$ \\
\hline Model & Gau & Gau & Gau & Gau & Gau & $\mathrm{Gau}$ & Gau & \\
\hline $\mathrm{C}_{0}$ & 21.2 & 32.9 & 0.1 & 1.0 & 1.5 & 1.0 & 0.1 & \\
\hline $\mathrm{C}_{0}+\mathrm{C}$ & 113.0 & 124.2 & 164.1 & 329.6 & 114.2 & 123.3 & 153.1 & \\
\hline Range (m) & 12 & 12 & 14 & 14 & 14 & 14 & 14 & \\
\hline SDD & $\mathrm{F}$ & M & $\mathrm{F}$ & $\mathrm{F}$ & $\mathrm{F}$ & $\mathrm{F}$ & $\mathrm{F}$ & \\
\hline $\mathrm{R}^{2}$ & 0.490 & 0.351 & 0.695 & 0.699 & 0.692 & 0.597 & 0.619 & \\
\hline RSS & 3267 & 5299 & 10286 & 40626 & 3979 & 6672 & 12236 & \\
\hline
\end{tabular}

C.V.= Variation coefficient (\%); $\mathrm{P}<\mathrm{W}=$ normality test result; $\mathrm{N}-\mathrm{N}=$ Non-normal distribution $(\mathrm{P}<\mathrm{W}<0.01) ;$ Gau $=$ Gaussian; $\mathrm{C}_{0}=$ Nugget effect; $\mathrm{C}_{0}+\mathrm{C}=$ Sill; $\mathrm{SDD}=$ Spatial dependence degree; $\mathrm{M}=$ Moderate; $\mathrm{F}=$ Strong; RSS = Residual sum of squares.

TABLE 8. Results of the descriptive statistics and semivariogram parameters of soil base saturation (\%), from 0 to 0.1 and from 0.1 to $0.2 \mathrm{~m}$ depth, for four sampling intensities in a Rhodic Hapludox under no-tillage system.

\begin{tabular}{|c|c|c|c|c|c|c|c|c|}
\hline \multirow[b]{3}{*}{ Statistics } & \multicolumn{8}{|c|}{ Number of Sampling Points } \\
\hline & 100 & 75 & 50 & 25 & 100 & 75 & 50 & 25 \\
\hline & \multicolumn{4}{|c|}{0 to $0.1 \mathrm{~m}$} & \multicolumn{4}{|c|}{0.1 to $0.2 \mathrm{~m}$} \\
\hline Average & 44 & 44 & 42 & 45 & 40 & 41 & 37 & 40 \\
\hline Medium & 41 & 41 & 39 & 38 & 34 & 36 & 32 & 35 \\
\hline Minimum & 16 & 16 & 19 & 22 & 11 & 11 & 12 & 12 \\
\hline Maximum & 96 & 96 & 96 & 96 & 94 & 94 & 94 & 94 \\
\hline C.V. & 44 & 45 & 42 & 45 & 55 & 55 & 55 & 58 \\
\hline Asymmetry coefficient & 1.02 & 1.03 & 1.16 & 1.37 & 1.02 & 1.01 & 1.22 & 1.33 \\
\hline Kurtosis coefficient & 0.59 & 0.53 & 1.33 & 1.42 & 0.32 & 0.21 & 1.31 & 1.28 \\
\hline $\mathrm{P}<\mathrm{W}$ & 0.00 & 0.00 & 0.00 & 0.00 & 0.00 & 0.00 & 0.00 & 0.00 \\
\hline Normality & $\mathrm{N}-\mathrm{N}$ & $\mathrm{N}-\mathrm{N}$ & $\mathrm{N}-\mathrm{N}$ & $\mathrm{N}-\mathrm{N}$ & $\mathrm{N}-\mathrm{N}$ & $\mathrm{N}-\mathrm{N}$ & $\mathrm{N}-\mathrm{N}$ & $\mathrm{N}-\mathrm{N}$ \\
\hline Model & Gau & Gau & Gau & Gau & Gau & Gau & Gau & Gau \\
\hline $\mathrm{C}_{0}$ & 31.4 & 45.7 & 0.1 & 10.0 & 40.2 & 36.0 & 51.1 & 20.0 \\
\hline $\mathrm{C}_{0}+\mathrm{C}$ & 138.6 & 130.9 & 236.8 & 298.1 & 228.1 & 210.4 & 308.7 & 410.9 \\
\hline Range (m) & 12 & 12 & 13 & 14 & 12 & 13 & 14 & 14 \\
\hline SDD & F & M & F & $\mathrm{F}$ & $\mathrm{F}$ & F & $\mathrm{F}$ & $\mathrm{F}$ \\
\hline $\mathrm{R}^{2}$ & 0.675 & 0.645 & 0.537 & 0.714 & 0.769 & 0.649 & 0.577 & 0.566 \\
\hline RSS & 1971 & 1369 & 24490 & 17158 & 4180 & 6755 & 20724 & 53882 \\
\hline
\end{tabular}

C.V.= Coefficient of variation (\%); $\mathrm{P}<\mathrm{W}=$ normality test result; $\mathrm{N}-\mathrm{N}=$ Non-normal distribution $(\mathrm{P}<\mathrm{W}<0.01) ;$ Gau $=$ Gaussian; $\mathrm{C}_{0}=$ Nugget effect; $\mathrm{C}_{0}+\mathrm{C}=$ Sill; $\mathrm{SDD}=$ Spatial dependence degree; $\mathrm{M}=$ Moderate; $\mathrm{F}=$ Strong; RSS = Residual sum of squares.

After removing the trend, it was possible to adjust the Gaussian model for $\mathrm{Ca}^{+2}$ (Table 6), $\mathrm{Mg}^{2+}$ (Table 7) and $\mathrm{V}$ values (Table 8), at depths and sample intensities studied. Similar results were obtained by REICHERT et al. (2008), working with a Planosol and sample grid of 240 points spaced $8 \mathrm{~m}$.

The range of values for attributes $\mathrm{pH}, \mathrm{Ca}^{2+}, \mathrm{Mg}^{2+}$ and $\mathrm{V}$ were similar to the sample intensities studied (100; 75; 50 and 25 points). The greatest change in the value range was observed for $\mathrm{pH}$ values (Table 5), which increased from 10 to $50 \mathrm{~m}$ in intensity points 15 to $25 \mathrm{~m}$ in intensity points. 
It is expected similarity in the pattern of spatial distribution of soil $\mathrm{Ca}^{2+}$ and $\mathrm{Mg}^{2+}$ and $\mathrm{pH}$ and $\mathrm{V}$ values since these variables are correlated.

It was observed that, although the Gaussian model has been adjusted for $\mathrm{pH}, \mathrm{Ca}^{2+}, \mathrm{Mg}^{2+}$ and $\mathrm{V}$ in all sample intensities and, even the range values being similar among sampling intensities, the effect nugget and sill had a significant variation among the sampling intensities (Tables 5; 6; 7 and 8). The greatest variation in the values of the nugget effect and the sill was observed for $\mathrm{Ca}^{2+}$, the value of nugget effect is 111.1 in sampling intensity with 75 points and 1.0 in intensity with 25 points. The sill values were from 413.1 in the sample intensity with 100 points to $1,240.0$ when using 25 points (Table 6).

This fact meant that the variables presented classification of the degree of spatial dependence in function of different sampling intensities. The degree of spatial dependence for the $\mathrm{Ca}^{2+}, \mathrm{Mg}^{2+}$ and $\mathrm{V}$ values, was classified as moderate using 75 points for the depth 0 to $0.1 \mathrm{~m}$, while, for the remaining sample intensities, it was classified as strong (Tables 6;7 and 8). The change in the degree of spatial dependence of soil attributes can generate changes in the accuracy of isoline maps, since the accuracy of these maps is closely related to the degree of spatial dependence of the measured attribute (KRAVCHENKO, 2003).

It was found that the spatial distribution of soil attributes was different depending on the sampling intensity. It can be noted that the soil $\mathrm{P}$ and $\mathrm{K}^{+}$values presented the greatest variations in spatial distribution, being possible to verify the spatial dependence only when it was used the sample intensities with 100 and 75 points.

These results are in accordance with those obtained by MALLARINO \& WITTRY (2004), when they studied strategies to perform the sampling of soil more efficiently in eight fields of agricultural production in the USA. The authors found that for all the strategies investigated the sampling efficiency was lower for the attributes $\mathrm{P}$ and $\mathrm{K}^{+}$in comparison with $\mathrm{pH}$ and $\mathrm{OM}$. Likewise, SOUZA et al. (2006) noted the need to collect a larger number of samples for the determination of the spatial distribution of the levels of $\mathrm{P}$ and $\mathrm{K}^{+}$in an Eutroferric red latosol under cultivation of sugar cane. This occurs due to constant fertilization with $\mathrm{P}$ and $\mathrm{K}^{+}$in the areas of agricultural production (CORÁ \& BERALDO, 2006), which affects the spatial distribution pattern, particularly those attributes.

Observing the results of this study, it was possible to separate the soil attributes into two groups according to their spatial variability. The first group, with greater spatial variability, was formed by the variables $\mathrm{P}$ and $\mathrm{K}^{+}$, and a second group, with less variability, was formed by varying amounts of clay, $\mathrm{Ca}^{2+}, \mathrm{Mg}^{2+}$ and $\mathrm{V}$ values. To define the spatial distribution pattern for the first group, the minimum sampling rate was 75 points, while for the second group, 50 sampling points were sufficient. However, to verify correlation with the productivity of maize, only the sample intensity with 100 points was efficient.

The use of single sample intensity for all attributes studied was not adequate, therefore, the soil characteristics showed different patterns of spatial distribution. This reinforces the importance of knowledge of the spatial variability of soil attributes for proper soil management and, consequently, the crop management. It also demonstrates that, for each attribute or group of attributes soil, it is necessary different sample intensities. However, in practice, it is usually used one sample intensity for studies related to the determination of the soil distribution patterns. Thus, it is necessary to use a sampling intensity capable of determining the spatial distribution of attribute that presents the lowest range. For the present study, the sampling intensity that allowed defining the spatial distribution pattern for the $\mathrm{K}^{+}$and $\mathrm{P}$, which had the lowest range, was the one with 75 points.

The model adjusted to the data of corn yield was spherical with nugget effect $\left(\mathrm{C}_{0}\right)=0.139$; sill $=0.445$ and range $=22 \mathrm{~m}\left(\mathrm{R}^{2}=0.672\right.$ and $\left.\mathrm{RSS}=0.0186\right)$. This result differs from that obtained 
by FREDDI et al. (2006) that has adjusted the exponential model to the data of corn yield under conventional tillage, using a sampling grid with 66 points, spaced $10 \mathrm{~m}$.

To verify the spatial correlation between soil properties and corn yield it was estimated crossed semivariogram. It was selected cross semivariogram using corn yield data, clay contents (Figure 3a) and V values (Figure 3b), at depth 0 to $0.1 \mathrm{~m}$ and sampling intensity with 100 points. The Gaussian model was set with a range of $60 \mathrm{~m}$ for clay contents and $14 \mathrm{~m}$ for $\mathrm{V}$ values. Unlike simple semivariograms, the value of cross semivariogram range indicates how far the variables are spatially correlated (VIEIRA, 2000). It is important to note that the fitted model for the values of corn (Gaussian) was the same as that which were adjusted for levels of clays and V values. This indicates that the spatial distribution of corn yield was dependent on the clay and $\mathrm{V}$ values.

a)

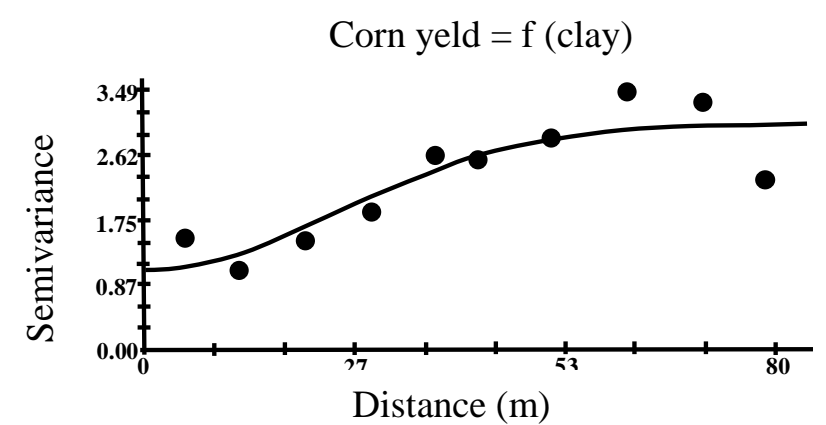

Gau $\left(\mathrm{C}_{0}=1.064 ; \mathrm{C}_{0}+\mathrm{C}=3.071 ; \mathrm{A}=60 \mathrm{~m} ; \mathrm{R}^{2}=0.80 ; \mathrm{RSS}=1.23\right)$ b)

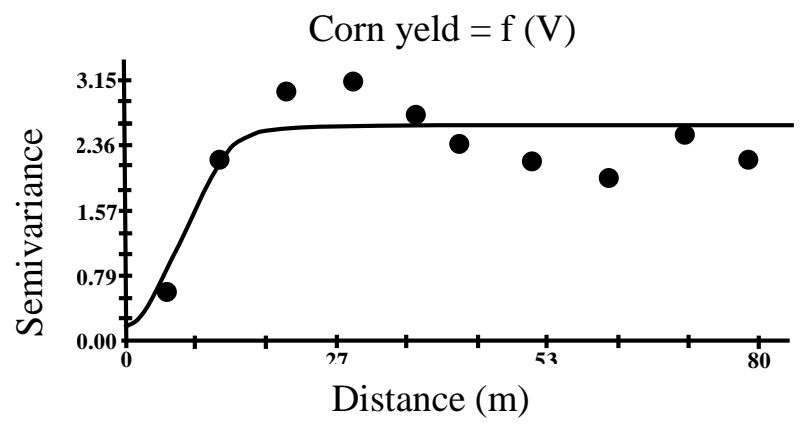

Gau $\left(\mathrm{C}_{0}=0.140 ; \mathrm{C}_{0}+\mathrm{C}=2.616 ; \mathrm{A}=16 \mathrm{~m} ; \mathrm{R}^{2}=0.71 ; \mathrm{RSS}=1.35\right)$

$\mathrm{V}=$ Base saturation; $\mathrm{Gau}=$ Gaussian $\mathrm{C}_{0}=$ Nugget effect $; \mathrm{C}_{0}+\mathrm{C}=\mathrm{Sill} ; \mathrm{A}=$ Range$; \mathrm{RSS}=$ Residual sum of squares .

FIGURE 3. Cross semivariogram between corn yield and clay content (a) and V values (b) for 100points sampling intensity in a Rhodic Hapludox under no-tillage system.

Observing the results obtained with the cross semivariogram, it appears that the data set relating to the attributes of the soil, obtained by sampling intensity with 100 points, was the best spatially correlated with corn yield. It confirmed the hypothesis that reducing the sampling intensity affects negatively the understanding of the spatial correlation between soil properties and yield of corn for this study.

\section{CONCLUSIONS}

It was confirmed the hypothesis of the study that the spatial distribution of soil attributes changes according to the sampling intensity, affecting the understanding of cause and effect relationships between the spatial distribution of crop yield and soil properties.

Soil $\mathrm{P}$ and $\mathrm{K}^{+}$values showed greater spatial variability, while the clay, $\mathrm{Ca}^{2+}, \mathrm{Mg}^{2+}$ and $\mathrm{V}$ had the lowest spatial variability, indicating that the sampling intensity to determine the spatial distribution pattern is dependent on the soil attribute studied.

The clay and V values obtained with the sampling intensity with 100 points were the soil attributes that best correlated to corn yield data, providing better understanding of cause and effect relationships between corn yield and soil attributes.

\section{ACKNOWLEDMENTS}

The São Paulo Research Foundation (FAPESP), by granting master's scholarship to the first author (Process 2008/52559-3). 


\section{REFERENCES}

AMARO FILHO, J.; NEGREIROS, R. F. D. D.; ASSIS JÚNIOR, R. N. D.; MOTA, J. C. A. Amostragem e variabilidade espacial de atributos físicos de um latossolo vermelho em Mossoró, RN. Revista Brasileira de Ciência do Solo, Viçosa, v.31, n.3, p.415-422, 2007.

CAMARGO, L. A.; MARQUES JÚNIOR, J.; PEREIRA, G. T.; HORVAT, R. A. Variabilidade espacial de atributos mineralógicos de um latossolo sob diferentes formas do relevo: II - correlação espacial entre mineralogia e agregados. Revista Brasileira de Ciência do Solo, Viçosa, v.32, n.6, p.2279-2288, 2008.

CAMARGO, O.A.; MONIZ, A.C.; JORGE, J.A.; VALADARES, J.M.S. Métodos de análise química, mineralógica e física de solos do Instituto Agronômico. Campinas: Instituto Agronômico, 1986. 94p. (Boletim Técnico, 106).

CAMBARDELLA, C. A.; MOORMAN, T. B.; NOVAK, J. M.; PARKIN, T. B.; KARLEN, D. L.; TURCO, R. F.; KONOPKA, A. E. Field-scale variability of soil properties in central Iowa soils. Soil Science Society of America Journal, v.58, n.5, p.1501-1511, 1994.

CARVALHO, J. R. P. D.; SILVEIRA, P. M. D.; VIEIRA, S. R. Geoestatística na determinação da variabilidade espacial de características químicas do solo sob diferentes preparos. Pesquisa Agropecuária Brasileira, Brasília, v.37, n.8, p.1151-1159, 2002.

CAVAlCANTE, E. G. S.; ALVES, M. C.; SOUZA, Z. M. D.; PEREIRA, G. T. Variabilidade espacial de atributos químicos do solo sob diferentes usos e manejos. Revista Brasileira de Ciência do Solo, v.31, n.6, p.1329-1339, 2007b.

CAVALCANTE, E. G. S.; MARLENE, C. A.; GENER, T. P.; ZIGOMAR, M. S. Variabilidade espacial de MO, P, K e CTC do solo sob diferentes usos e manejos. Ciência Rural, Santa Maria, v.37, n.2, p.394-400, 2007a.

COELHO, A. M. Agricultura de precisão: manejo da variabilidade espacial e temporal dos solos e das culturas. In: CURI, N. M., J. J.; GUILHERME, L. R. G.; LIMA, J. M.; LOPES, A. S.; ALVAREZ VENEGAS, V. H. (Ed.). Tópicos em ciência do solo. Viçosa: Sociedade Brasileira de Ciência do Solo, 2003. v.3, p.243-290.

CORÁ, J. E.; ARAUJO, A. V.; PEREIRA, G. T.; BERALDO, J. M. G. Variabilidade espacial de atributos do solo para adoção do sistema de agricultura de precisão na cultura de cana-de-açúcar. Revista Brasileira de Ciência do Solo, Viçosa, v.28, n.6, p.1013-1021, 2004.

CORÁ, J. E.; BERALDO, J. M. G. Variabilidade espacial de atributos do solo antes e após calagem e fosfatagem em doses variadas na cultura de cana-de-açúcar. Engenharia Agrícola, Jaboticabal, v.26, n.2, p.374-387, 2006.

DAVIS, J. C. Statistics and data analysis in geology. New York: John Wiley, 1973. 550 p.

FREDDI, O. S.; CARVALHO, M. P.; VERONESI JÚNIOR, V.; CARVALHO, G. J. Produtividade do milho relacionada com a resistência mecânica à penetração do solo sob preparo convencional. Engenharia Agrícola, Jaboticabal, v.26, n.1, p.113-121, 2006.

GOMES, J. B. V.; BOLFE, E. L.; CURI, N.; FONTES, H. R.; BARRETO, A. C.; VIANA, R. D. Variabilidade espacial de atributos de solos em unidades de manejo em área piloto de produção integrada de coco. Revista Brasileira de Ciência do Solo, Viçosa, v.32, n.6, p.2471-2482, 2008.

KITAMURA, A. E.; CARVALHO, M. D. P. E.; LIMA, C. G. D. R. Relação entre a variabilidade espacial das frações granulométricas do solo e a produtividade do feijoeiro sob plantio direto. Revista Brasileira de Ciência do Solo, Viçosa, v.31, n.2, p.361-369, 2007.

KRAVCHENKO, A. N. Influence of spatial structure on accuracy of interpolation methods. Soil Science Society of America Journal, Madison, v.67, n.5, p.1564-1571, 2003. 
MACHADO, L. D. O.; LANA, Â. M. Q.; LANA, R. M. Q.; GUIMARÃES, E. C.; FERREIRA, C.V. Variabilidade espacial de atributos químicos do solo em áreas sob sistema plantio convencional. Revista Brasileira de Ciência do Solo, Viçosa-MG, v.31, n.3, p.591-599, 2007.

MALLARINO, A.; WITTRY, D. Efficacy of Grid and Zone Soil Sampling Approaches for SiteSpecific Assessment of Phosphorus, Potassium, pH, and Organic Matter. Precision Agriculture, Dordrecht, v.5, n.2, p.131-144, 2004.

MEGDA, M. M.; CARVALHO, M. D. P. E.; VIEIRA, M. X.; ANDREOTTI, M.; PEREIRA, E. C. Correlação linear e espacial entre a produtividade de feijão e a porosidade de um Latossolo Vermelho de Selvíria - MS. Revista Brasileira de Ciência do Solo, Viçosa, v.32, n.2, p.781-788, 2008.

MELLO, G. D.; BUENO, C. R. P.; PEREIRA, G. T. Variabilidade espacial das propriedades físicas e químicas do solo em áreas intensamente cultivadas. Revista Brasileira de Engenharia Agrícola e Ambiental, Campina Grande, v.10, n.2, p.294-305, 2006.

MUELLER, T. G.; PIERCE, F. J.; SCHABENBERGER, O.; WARNCKE, D. D. Map quality for site-specific fertility management. Soil Science Society of America Journal, Madison, v.65, n.5, p.1547-1558, 2001.

PIMENTEL-GOMEZ, F.; GARCIA, C.H. Estatística aplicada a experimentos agronômicos e florestais: exposição com exemplos e orientações para uso de aplicativos. Piracicaba, FEALQ, 2002. 309 p.

RAIJ, B. VAN; ANDRADE, J.C.; CANTARELLA, H.; QUAGGIO, J.A. Análise química para avaliação da fertilidade de solos tropicais. Campinas: Instituto Agronômico, 2001. 285 p.

RAIJ, B. van; CANTARELLA, H.; QUAGGIO, J.A.; FURLANI, A.M.C. (Ed.). Recomendações de adubação e calagem para o Estado de São Paulo. 2.ed. Campinas: Instituto Agronômico/Fundação IAC, 1997. 285 p. (Boletim Técnico, 100).

REICHERT, J. M.; DARIVA, T. A.; REINERT, D. J.; SILVA, V. R. D. Variabilidade espacial de Planossolo e produtividade de soja em várzea sistematizada: análise geoestatística e análise de regressão. Ciência Rural, Santa Maria, v.38, n.4, p.981-988, 2008.

SHAPIRO, S. S.; WILK, M. B. An analysis of variance test for normality (complete samples). Biometrika, London, v.52, n.3-4, p.591-611, 1965.

SOUZA, Z. M.; MARQUES JÚNIOR, J.; PEREIRA, G. T.; MONTANARI, R.; CAMPOS, M.C.C. Amostragem de solo para determinação de atributos químicos e físicos em áreas com variação nas formas do relevo. Científica, Jaboticabal, v.34, n.2, p.249-256, 2006.

THOMPSON, A.N.; SHAW, J.N.; MASK, P.L.; TOUCHTON, J.T.; RICKMAN, D. Soil sampling techniques for Alabama, USA Grain Fields. Precision Agriculture, New York, v.5, n.4, p.345-358, 2004.

VIEIRA, S.R. Geoestatística em estudos de variabilidade espacial do solo. In: NOVAIS, P. F.; ALVAREZ, V.H.; SCHAEFER, C.E.G.R. Tópicos em ciência do solo. Viçosa: Sociedade Brasileira de Ciência do Solo, 2000. v.1, p.1-54. 